\title{
BILOU DAN TANTANGAN MENGKONSERVASINYA DI MENTAWAI: Sebuah Tinjauan dari Perspektif Sosial Budaya
}

\author{
Edi Indrizal \\ Received Article: 10 Oktober 2016 \\ Accepted Article:17 November 2016
}

\begin{abstract}
This article is a scientific essay contains a main thought about the needed for social accomodate cultural perspective in effort of conservation of bilou (Hylobates Klossii) in the Mentawai Islands. The author means to show the need for an integrated approach, covering social cultural perspective in order to conservation Bilou development. In one side internally, perception and utilization of Bilou in the life of traditional Mentawai people closely related with a system of belief, customs and habits of their own life. On the other side, Mentawai people also confronted with the various forms of packaging modernity who promoted and maybe pushed by outside parties. In the middle of the threat of extinction of Bilou in the Mentawai Islands in this day, its important to get lessons from local wisdom and selected to become part of approach and instrument of conservation Bilou integrated. As also important to review a various forms of promotion modernity and development intervention that until now had been contraproductive to the purpose of Bilou conservation, covering the needed for the new regulations and more consequent law enforcement.
\end{abstract}

Keywords: Bilou, Mentawai Islands, Local Wisdow, Conservation

\begin{abstract}
Abstrak
Tulisan ini merupakan sebuah essai ilmiah berisi pokok-pokok pemikiran tentang perlunya mengakomodasi perspektif sosial budaya dalam upaya pelestarian bilou (Hylobates klossii) di Kepulauan Mentawai. Penulis bermaksud menunjukkan perlunya pendekatan terpadu, meliputi persepektif sosial budaya dalam rangka pembangunan konservasi bilou. Di satu sisi secara internal persepsi dan pemanfaatan bilou dalam kehidupan tradisional orang Mentawai erat kaitannya dengan sistem kepercayaan, adat istiadat dan kebiasaan hidup suku asli Mentawai sendiri. Di sisi lain orang Mentawai juga dihadapkan dengan berbagai bentuk kemasan modernitas yang dipromosikan dan bahkan mungkin didesakkan "pihak luar". Di tengah-tengah ancaman kepunahan bilou di Kepulauan Mentawai dewasa ini, maka amatlah penting memetik pembelajaran dari kearifan lokal setempat dan menyeleksinya untuk dijadikan bagian dari pendekatan dan intrumen terpadu pelestarian bilou. Sebagaimana juga penting meninjau ulang berbagai bentuk promosi modernitas dan intervensi pembangunan yang selama ini kontra-produktif terhadap tujuan konservasi bilou, meliputi perlunya regulasi baru dan penegakan hukum yang lebih konsekuen.
\end{abstract}

Kata Kunci: Bilou, Kepulauan Mentawai, Kearifan lokal, Pelestarian

\footnotetext{
${ }^{1}$ Penulis adalah Dosen tetap Jurusan Antropologi FISIP Universitas Andalas Bilou Dan Tantangan Mengkonservasinya Di Mentawai
} 


\section{A. Pendahuluan}

$B$ lou (Hylobates klossii) merupakan salah satu kekayaan keanekaraga man hayati jenis primata endemik yang adanya hanya di Kepulauan Mentawai. Bentuk fisiknya seperti siamang berbulu hitam berseri tetapi ukuran postur badannya mungil, karenanya terlihat unik dan indah. Merujuk katalog keanekaragaman hayati yang dipublikasikan Yayasan KEHATI (2015) dikatakan bahwa bilou (siamang kerdil Mentawai) merupakan jenis gibon yang paling primitif. Primata ini dikenal amat pandai bernyanyi. Nyanyian yang bersahutsahutan selama 10 menit hingga dua jam di pagi hari bisa berisi 12 not dan sebuah trill menyemarakkan eksotiknya hutan Menta wai. Nyanyian bilou betina dikatakan juga sebagai nyanyian terindah yang dilantunkan mamalia darat. Secara anatomis, bilou adalah jenis ungko tertua yang masih ada di muka bumi ini. Bulu-bulu yang jarang berwarna hitam gelap diselingi selaput antara jari kedua dan ketiga. Bilou memerlukan ragam pohon-pohonan hutan dewasa yang dapat menyediakan berbagai jenis makanan dan buah-buahan yang masak sepanjang tahun. Pohon besar di hutan menjadi tempat tidurnya dengan kanopi yang bersambungan sebagai tempat berjalan-jalan.

Dewasa ini sorotan perhatian untuk melestarikan bilou Mentawai ini semakin banyak dilakukan berbagai pihak. Baik kalangan akademisi, praktisi lingkungan, pemerintah bahkan hingga masyarakat internasional intens mendiskusikan strategi dan langkah-langkah aksi untuk mengkon servasinya. Betapa tidak, meskipun bilou telah lama ditetapkan sebagai satwa dilindungi, namun populasinya terus mengalami penurunan dan terancam punah. Dari populasinya yang tersisa di alam bebas, primata endemik Mentawai ini kini tinggal hanya ada di Pulau Siberut.

Sejatinya tantangan pelestarian bilou bersifat kompleks. Di antara persoalan penting yang dihadapi terkait hubungannya dengan cara pandang dan perilaku manusia terhadap bilou itu sendiri. Dalam rangka membangun strategi dan rencana aksi konservasi bilou ke depan oleh karenanya diperlukan pemahaman yang lebih komprehensif terhadap kompleksitas persoalannya, termasuk dibutuhkannya tinjauan dari perspektif sosial budaya sebagai pendekatan pembangunan terpadu konservasi bilou ini. Sebagian isi pokok pikiran penulis ini pernah disampaikan pada acara Diskusi Tematik dan Lokakarya "Strategi dan Rencana Aksi Konservasi Bilou (Hylobates klossii)" yang diselenggarakan oleh Flora \& Fauna Indonesia - Indonesia Programme dan Direktorat Jenderal PHKA Kementerian Lingkungan Hidup dan Kehutanan RI, di Padang: 24 Februari 2015.

\section{B. Pelestarian Bilou dari Perspektif Sosial Budaya}

$\mathrm{S}$ ekurang-kurangnya ada dua hal pokok dari perspektif sosial budaya yang perlu mendapatkan perhatian dalam rangka pelestarian bilou. Kedua hal pokok yang akan penulis didiskusikan berikut ini menyangkut persepsi dan pemanfaatannya oleh masyarakat, serta implikasi ancaman terhadap kepunahan bilou yang bisa saja berlainan, berseberangan, atau bahkan bisa pula justru berkulindan satu sama lain.

Pertama, persepsi dan pemanfaatan yang ditunjukkan lewat perlakuan masya rakat luas ("orang luar" Mentawai) terhadap bilou. Bentuk fisik bilou yang unik, indah dan menarik serta perilakunya yang pemalu, menjadikannya sebagai satwa paling mahal sekaligus paling dicari dari hutan Mentawai. Walaupun tidak mudah dibuktikan namun sudah cukup lama santer terdengar bilou menjadi sasaran perburuan ilegal dan komoditas perdagangan gelap oleh 'orang seberang' (sebutan orang Mentawai kepada warga yang bukan penduduk asli Mentawai). Bahkan bilou diketahui juga dijadikan semacam hadiah cendera mata bernilai istimewa kepada pejabat yang hobby satwa langka, atau oleh-oleh tanda pernah bertugas atau pernah berkunjung ke Kepulauan Mentawai. Sebagai satwa langka yang diminati untuk dijadikan peliharaan, bilou dicari oleh pecintanya dari dalam negeri hingga mancanegara.

Dalam hal bilou dijadikan sasaran perburuan ilegal biasanya dilakukan dengan cara menggunakan senjata senapan angin berpeluru yang diberi racun terlebih dahulu. 
Perburuan ke dalam hutan umumnya melibatkan penduduk tempatan yang dianggap lebih mengetahui medan. Penggunaan racun tradisional dari bahan alam setempat pada peluru senapan angin menguatkan keterlibatan penduduk pribumi dalam aktivitas ini. Target utama perburuan biasanya adalah anak bilou yang masih diemong induknya. Induknya ditembak sehingga anaknya terlepas agar mudah ditangkap hidup-hidup. Anak bilou yang paling dicari adalah berjenis kelamin betina karena kelak dinilai lebih "ramah" untuk dipelihara. Cara dan pilihan target perbu ruan seperti ini sungguh bersifat akumulatif sebagai ancaman terhadap punahnya bilou dari bumi "si Kerei" Mentawai.

Berdasarkan hasil suatu investigasi yang dilakukan oleh Polhut BTNS pada Tahun 2014 harga jual anak bilou ketika sudah sampai di Padang minimal Rp. 3 juta seekor. Selanjutnya meski praktik perdagangan gelap bilou ini belum cukup banyak diketahui, namun hal ini amatlah penting menjadi sorotan perhatian dalam upaya menyelamatkan bilou dari ancaman kepunahannya. Di satu sisi seiring peruba han gaya hidup sebagian masyarakat kota dan kalangan kaya, maka tuntutan untuk menangkap bilou dalam keadaan hidup pun meningkat untuk dijadikan peliharaan hewan hobby. Kalaupun didapatkan dalam keadaan mati, maka ia bisa juga dijadikan pajangan bernilai prestise untuk diletakkan di ruang tamu, ruang kerja, ataupun ruang khusus lainnya.

Hingga kini ancaman ini tetaplah nyata. Sebagaimana terungkap dari pengalaman seorang Polhut yang bertugas di Balai Taman Nasional Siberut (BTNS) sejak Tahun 2012, setiap tahunnya (20122014) selalu saja ada kasus penangkapan bilou untuk dibawa ke luar dari Pulau Siberut, Kepulauan Mentawai. Rute jalurnya ada yang melewati pelabuhan di Kota Padang, dan ada pula lewat Kabupaten Pesisir Selatan. Ironisnya, dalam beberapa kasus ditemukan keterlibatan oknum aparat keamanan (Polri/TNI). Sungguh disayang kan kasus-kasus perburuan ilegal maupun perdagangan gelap satwa langka ini biasanya tidak sampai diselesaikan tuntas lewat pengadilan.
Seiring meningkatnya komersialisasi dan monetisasi terutama ditandai dengan perembesan nilai uang ke dalam sendisendi kehidupan orang Mentawai sendiri maka tuntutan dan godaan dari 'orang seberang' sulit menahan orang Mentawai untuk tidak terlibat dalam penangkapan dan perdagangan bilou. Penduduk pribumi dijadikan ujung tombak perburuan ilegal di hutan-hutan Mentawai, minimal sebagai penunjuk lokasi atau pemandu jalan ke hutan bertajuk tinggi di pedalaman tempat hidupnya kelompok bilou. Sedangkan dalam perdagangannya, tercatat ada beberapa kasus dimana oknum Kepala Desa pun turut terlibat. Pertanda praktik perburuan ilegal dan perdagangan gelap bilou ini memanglah cukup serius untuk dicarikan cara pemecahan masalahnya.

Kedua, terkait kedudukan dan arti bilou dalam kehidupan masyarakat dan kebudayaan tradisional di Kepulauan Mentawai. Meskipun sudah banyak studi tentang masyarakat Mentawai selama ini (Sihombing, 2960; Spina, 1981; Schefold, 1985 dan 1991; Persoon dan Schefold, 1985) yang didominasi berdasarkan penelitian di P. Siberut, namun sedikit yang memperbincangkan secara khusus tentang interaksi antara masyarakat lokal dengan bilou. Seorang antropolog ahli Mentawai Reimar Schefold (1985 dan 1991) menyebutkan bahwa orang Mentawai melukiskan roh seperti dengan manusia, dimana roh juga suka pesta, makan enak, menari dan dibuatkan mainan. Mainan bagi roh dilakukan agar roh tidak bosan, sehingga tetap tinggal bersama mereka, karena bila roh tidak lagi kerasan tinggal bersama mereka dan kemudian pergi merupakan bencana yang dapat berakibat sakit atau kematian bagi orang Mentawai. Dengan demikian banyak aspek tingkah laku orang Mentawai berhubungan dengan ketentraman roh, yang berarti ketentraman bagi mereka juga. Selain itu untuk menyenangkan para roh juga dibuatkan mainan yang indah-indah. Diasumsikan lahir dan berkembangnya benda-benda seni yang indah merupakan wujud dari bentuk hubungan yang selaras dan harmoni antara manusia, alam dan roh yang merupakan dua komunitas berbeda yang hidup berdampingan. Demikian pula berbagai 
tarian tradisional Mentawai dengan variasi gerakan meniru satwa, kesemuanya menunjukkan bentuk interaksi dan adaptasi masyarakat dengan alam.

Perwujudan berbagai tradisi upacara, kekhasan karya seni dan praktik berburu tradisional di Mentawai jelas tidak terlepas dari pengaruh religius sistem kepercayaan yang begitu kental dalam kehidupan orang Mentawai. Hingga dewasa ini penyelenggaraan berbagai upacara itu seperti punen, puliaijat dan upacara seremonial lainnya pun masih dapat ditemukan walaupun dalam takaran yang berbeda-beda antara desa-desa di pedalaman. Secara khusus dicatat oleh Rahmadi dalam katalog kenaekaragaman hayati Yayasan KEHATI (2015) bahwa bilou biasanya dimanfaatkan oleh masyarakat Mentawai dalam upacara eneget yaitu upacara peralihan hidup memperingati perubahan fase pertumbuhan anak laki-laki ke tahap dewasa.

Orang Mentawai juga meman faatkan bilou untuk dijadikan benda-benda indah atau kerajinan yang indah (maeru'). Hasil primata buruan kemudian tengkoraknya disusun sedemikian rupa menyeruapai hiasan di rumah para si kerei juru pengobatan tradisional di Mentawai. Benda-benda karya seni ini biasanya juga meliputi ukiran dari kayu yang dipahat dengan aneka macam motif kekayaan alam Mentawai, temasuk bilou. Dari tata peletakannya di rumah para kerei itu akan tampak posisi kerajinan pahatan kayu bermotif bilou biasanya dipasang paling tinggi di antara yang lainnya.

Di dalam upacara-upacara tradi sional, hasil-hasil kerajinan seni dari pemanfaatan tengkorak primata hasil buruan maupun ukiran pahatan kayu biasanya semakin jelas bisa terlihat. Pada saat pelaksanaan upacara tradisional pula bisa dijumpai tarian khas Mentawai, termasuk tarian yang menggunakan nama bilou, berciri-cirikan gerakan-gerakan unik menyerupai bilou. Sehubungan dengan ini amatlah menarik untuk mencermati bahwa tarian bilou adalah merupakan salah satu tarian terpopuler bagi orang Mentawai.

Sebagaimana terkonfirmasi lewat forum-forum diskusi dan catatan-catatan hasil kunjungan lapangan dan kupasan media lokal, sekurang-kurangnya ada sejumlah informasi penting yang relevan

Bilou Dan Tantangan Mengkonservasinya Di Mentawai terkait persepsi dan pemanfaatan bilou oleh orang Mentawai hingga dewasa ini. Bagi orang pribumi Mentawai yang merupakan komunitas adat asli dan polupasi terbesar hidup turun temurun di Kepulauan Mentawai sejatinya bilou memiliki kedudukan dan arti penting yang khas dalam kebudayaan setempat, khususnya dengan sistem kepercayaan arat sabulungan. Sistem kepercayaan tradisional yang sering disebutkan berlatar animisme ini telah memberikan muatan religius pada hampir semua sisi tradisi yang pada kenyataannya tetap hidup di beberapa daerah di pedalaman Kepulauan Mentawai hingga dewasa ini. Hal ini antara lain masih dapat terlihat dari adanya upacara pengobatan, pesta-pesta ritual, pemberian sesajian dan sebagainya yang masih diselenggarakan. Meskipun telah mengenal agama modern dengan masuknya Kristen dan Islam, sistem kepercayaan tradisional hingga kini tetaplah penting bagi orang Mentawai. Berbagai kemasan modernitas yang dilakukan berbagai pihak luar berupa ideologi agama, nilai dan norma-norma baru tidaklah begitu saja bisa menggeser peranan ideologi dan kepercayaan tradisional masyarakat Mentawai.

Di dalam sistem idoelogi budaya Mentawai semua benda, hidup atau mati, nyata atau tidak nyata, semuanya diyakini memiliki jiwa atau roh (simagere). Apakah itu manusia, hewan, pohon, rumah, sungai, perahu, panah dan sebagainya dipercaya memiliki roh. Singkatnya, seperti masyarakat manusia, roh dipercaya juga memiliki komunitas tersendiri. Untuk itu manusia harus menjaga keseimbangan dan kesinambungan hubungan mereka dengan para roh. melalui keselarasan dan kehar monisan. Inilah sebenarnya inti kehidupan orang Mentawai, bagaimana interaksi antara sesama manusia dengan para roh terselenggara secara seimbang.

Di dalam kehidupan masyarakat tradisional suku asli Mentawai hingga kini masih dikenal penyelenggaraan berbagai upacara. Melalui serangkaian upacara tradisional punen, puliaijat, pesta-pesta ritual, sesaji dan sebagainya ditujukan agar roh selalu merasa senang dan betah tinggal serta dapat melindungi para penghuni uma. Pada setiap upacara tradisional itu biasanya dijumpai pula konsumsi hewan hasil buruan, baik dalam rangka pemanfaataan sebagai 
syarat pengobatan maupun untuk konsumsi protein. Berkenaan dengan ini bilou memiliki kedudukan khusus sebagai satwa yang sesungguhnya pantangan atau tidak boleh dijadikan sasaran perburuan. Praktik perburuan tradisional orang Mentawai sendiri sebenarnya memiliki kearifan lokal sebab hanya dilakukan di saat bulan purnama atau hanya kurang lebih 3 hari dalam 1 tahun. Di dalam praktik berburu tradisional terdapat perlakuan berbeda terhadap bilou dibandingkan dengan primata Mentawai lainnya seperti joja atau lutung (Presbytis potenziani), bokkoi (Macaca pagensis) dan simakobu (Simias concolor) yang dijadikan sasaran utama perburuan. Bahkan apabila di saat berburu terdengar ada suara teriakan bilou, maka perburuan haruslah dihentikan.

Adanya suara dengan alunan bunyi tertentu dari bilou dianggap sebagai petanda akan ada bahaya. Sebagaimana juga pernah dilaporkan Harian Kompas (2009) dan Harian Republika (2009), secara turun temurun orang Mentawai memper cayai adanya hubungan antara suara bilou dengan pertanda akan datangnya bencana. Teriakan riuh bilou, merupakan pertanda sekaligus deteksi dini terjadinya tsunami. Nilai kepercayaan tradisional seperti ini tentu saja sesungguhnya bersifat positif bagi tujuan konservasi bilou.

Namun demikian penting juga untuk dicatat bahwa tidak semua kebudayaan tradisional selalu positif bagi tujuan konservasi. Sebaliknya bisa saja ada pula nilai dan tradisi yang justru kontradiktif terhadap tujuan konservasi. Dalam hal adanya tradisi perburuan terhadap jenis primata tertentu di Mentawai, meskipun pantang terhadap bilou, agaknya tidak mengurangi peluang eksesnya terhadap bilou itu sendiri. Di satu sisi seiring dikenalnya aktivitas berternak terutama babi dan ayam maka kini pilihan konsumsi hewan itu tidak lagi terbatas pada hasil hewan primata buruan. Di sisi lain tradisi berburu dan sebagian kepercayaan tradisional Mentawai sendiri bisa juga justru menjadi ancaman terhadap kelangsungan hidup seluruh primata endemik Mentawai, tidak kecuali bilou. Tradisi berburu orang Mentawai dapat menjadi mekanisme legitimasi atau 'pembenaran' dan sekaligus peluang untuk ditumpangi oleh perburuan bilou yang dipelopori 'orang seberang'. Apalagi seiring perubahan sosial yang ditandai meningkatnya perembesan nilai uang ke dalam berbagai sendi-sendi kehi dupan masyarakat Mentawai, tentu saja turut berdampak terhadap perubahan dalam aktivitas perburuan. Praktik perburuan orang Mentawai sekarang ini tidak lagi merujuk pada periode waktu tertentu bulan purnama saja. Begitu pula penggunaan alat panah tradisional kini sudah banyak, digantikan dengan senapan angin. Seiring perjalanan waktu, banyak pergeseran pun terjadi di Mentawai. Kegiatan upacara dan ritual keagamaan tradisional Mentawai seperti punen pun semakin jarang ditemukan di desa-desa pinggiran pantai sekitar pelabuhan, atau di pemukiman binaan Departemen Sosial, atau di desa-desa berlokasi di pusat kecamatan.

\section{Tantangan dalam Pelestarian Bilou}

U raian di atas memperlihatkan bahwa dari perspektif sosial budaya ada tantangan tersendiri dalam upaya pelestarian bilou. Tantangan sosial budaya itu meliputi yang bersumber dari masyarakat luas (orang luar Mentawai) maupun pen duduk tempatan suku asli Mentawai sendiri. Penulis menyebutnya sebagai tantangan karena dalam beberapa hal justru ditemukan segi-segi yang dapat menjelma sebagai kendala dalam melakukan konservasi bilou Mentawai. Bahkan jika luput dari perhatian maka dapat semakin sengkarut dengan persoalan lainnya yang selama ini juga sudah berlangsung lama menyangkut berbagai tekanan pembangunan di Kepu lauan Mentawai. Seiring makin berku rangnya tajuk-tajuk pepohonan hutan akibat intervensi eksploitasi kayu oleh HPH yang juga intensif di Mentawai, kesemua ini menyebabkan kehidupan bilou kian terdesak, dan semakin mudah untuk jadi korban sasaran perburuan. Ekspansi akumulasi kapital perusahaan HPH niscaya menjadi ancaman terhadap penyelamatan primata endemik Mentawai, bahkan terhadap kelangsungan hidup masyarakat suku asli Mentawai yang sejatinya bertumpu harmoni budaya dan keseimbangan alam. 


\section{Kesimpulan}

paya konservasi bilou perlu dilakukan lewat strategi pendekatan pembangunan yang terpadu. Kon servasi bilou hendaklah dilakukan terinte grasi dengan upaya memelihara kelang sungan identitas sosial budaya suku asli
Mentawai yang dijamin oleh adanya regulasi dan penegakan hukum secara konsekuen. Sungguh ironis jika agenda konservasi bilou yang makin intens dibincangkan tetapi menafikan perlindungan regulasi lokal dan penegakan hukum yang belum juga kunjung tegak nyata.

\section{Daftar Pustaka}

Departemen Kehutanan RI. 1995. Rencana Pengelolaan Taman Nasional Siberut (ICMP). Vol. 1-3. Proyek Pengembangan Konservasi Alam Terpadu di Flores (Ruteng) dan Siberut. ADB Loan No. 1187-IND (SF). Jakarta.

FFI dan GAIA. 2014. Inception Report Searching of Mentawai Primates Best Conservation Approach. Jakarta.

Mitchell, A. H. 1982. Siberut Nature Conservation Area ; Management Plan 1983-1988, WWF - IUCN. Bogor.

Persoon, G. dan R. Schefold (Eds.). 1985. Pulau Siberut. Jakarta. Bhratara.

Schefold, R. 1985. Keseimbangan Mentawai dan Dunia Modern dalam Michael R. Dove (Ed.). Peranan Kebudayaan Tradisional dalam Pembangunan. Jakarta. Yayasan Obor Indonesia.

Schefold, R. 1991. Mainan Bagi Roh: Kebudayaan Mentawai. Jakarta. Balai Pustaka.

Sihombing, H. 1960. Mentawai. Padang. Universitas Andalas.

Spina, B. 1981. Mitos dan Legenda Suku Mentawai. Jakarta. Balai Pustaka.

Harian Kompas. Jum'at 20 Maret 2009. "Teriakan Bilou Mentawai Jadi Deteksi Dini Tsunami".

Harian Republika. Sabtu 21 Maret 2009. "Nyanyian Bilou Mentawai Pertanda Dini Tsunami". Yayasan KEHATI. 2015. Biodiversity Warriors. Katalog. "Siamang Kerdil Mentawai" by. Fadli Rahmadi. 